\title{
Correction to: Functional unit influence on building life cycle assessment
}

\author{
Hugo Henrique de Simone Souza ${ }^{1} \cdot$ Patrícia Pereira de Abreu Evangelista $^{2} \cdot$ Diego Lima Medeiros $^{3} \cdot$ Jaume Albertí $^{4}$. \\ Pere Fullana-i-Palmer ${ }^{4} \cdot$ Marc Árpád Boncz $^{1}$. Asher Kiperstok ${ }^{3} \cdot$ Jardel Pereira Gonçalves ${ }^{2}$
}

Published online: 7 February 2022

๑) Springer-Verlag GmbH Germany, part of Springer Nature 2022

\section{Correction to: Int J Life Cycle Assess (2021). https://doi.org/10.1007/s11367-020-01854-1}

The original version of this article, unfortunately, contained five mistakes. Eq. 1 is missing the multiplication symbol before the CF variable. The correct version of Eq. 1 is presented hereafter:

$$
L C I A_{\text {building }(R S)}\left(L C I A_{\text {pre-op }}+L C I_{o p}+L C I_{\text {post }-o p}\right) \times C F
$$

Eq. 2 is missing the subscript format of the variables. The correct version of Eq. 2 is presented hereafter:

$$
\begin{aligned}
L C I A_{\text {building }(C S)=}= & \left(L C I A_{\text {pre-op }}+L C I A_{\text {post-op }}\right) \times A F_{L T} \\
& \times A F_{O D}+\left(L C I A_{o p}\right) \times A F_{L T} \times A F_{O D}
\end{aligned}
$$

The citation of "Eq. 5 and Eq. 6" should be corrected to "Eq. 6 and Eq. 7" in the following sentence: "However, the LT $_{\mathrm{RS}}$ in Eq. 6 and Eq. 7 was kept the same parameter of the reference FU from the reference scenario (RS) as in Evangelista et al. (2018);"

The citation of "OD $\mathrm{RS}_{\mathrm{RS}}$ in Eq. 6" should be corrected to "OD ${ }_{\mathrm{RS}}$ in Eq. 7" in the following sentence: "However, the $\mathrm{OD}_{\mathrm{RS}}$ in Eq. 7 was kept the same parameter of the reference FU from the reference scenario (RS) as in Evangelista et al. (2018);"

The variable " $\mathrm{OR}_{\mathrm{RS}}$ " should be corrected to " $\mathrm{OD}_{\mathrm{RS}}$ " in Eq. 7. The correct version of Eq. 7 is presented hereafter:

$L C I A_{\text {occupant }}=\frac{L C I A_{\text {dwelling-unit }}}{O D_{R S} \times L T_{R S} \times 365}$

Publisher's Note Springer Nature remains neutral with regard to jurisdictional claims in published maps and institutional affiliations.

The original article can be found online at https://doi.org/10.1007/ s11367-020-01854-1.

Hugo Henrique de Simone Souza

hugohenriquesouza@gmail.com; hugo.souza@ufms.br

1 Faculty of Engineering, Architecture and Urbanism, and Geography (FAENG), Environmental Technologies Postgraduate Program (PGTA), Federal University of Mato Grosso do Sul (UFMS), Av. Costa e Silva S/N, CEP, Campo Grande, MS 79070-900, Brazil

2 Energy and Environment Postgraduate Program (PGEnAm), Federal University of Bahia (UFBA), Rua Aristides Novis, $\mathrm{n}^{\circ}$ 2 CEP 40.210-630, BA, Federação Salvador, Brazil

3 Industrial Engineering Postgraduate Program (PEI), Federal University of Bahia (UFBA), Rua Aristides Novis, Escola Politécnican $^{\circ}$ 2, $6^{\circ}$ Andar Federação, CEP 40.210-630, Salvador, BA, Brazil

4 UNESCO Chair in Life Cycle and Climate Change ESCI-UPF, Pompeu Fabra University, Passeig Pujades n 1, 08003 Barcelona, Spain 